DOI: https://doi.org/10.11144/Javeriana.upsy16-4.vqsc

\title{
Validation of the Questionnaire "Stage of Change in Behavior of Scholars in Eating Habits and Physical Activity" (CEHAF)
}

\section{Validación del cuestionario "Etapa de cambio del comportamiento de los escolares en hábitos alimentarios y actividad física” (CEHAF)}

\author{
José María De la Roca Chiapas \\ Universidad de Guanajuato, México \\ ORCID: http://orcid.org//0000-0002-2563-403X \\ Luis Felipe García y Barragán \\ Universidad de Guanajuato, México \\ Claudia Susana Escalante Guerrero \\ Universidad de Guanajuato, México \\ Maciste Habacuc Macías Cervantes \\ Universidad de Guanajuato, México \\ María Elena Hernández Hernández \\ Universidad de Guanajuato, México
}

a Autor de correspondencia. Correo electrónico: josema_delaroca@yahoo.com.mx

Para citar este artículo: De la Roca, J. M., García y Barragán, L. F., Escalante, C. S., Macías, M. H., \& Hernández, M. E. (2017). Validation of the Questionnaire "Stage of Change in Behavior of Scholars in Eating Habits and Physical Activity" (CEHAF). Universitas Psychologica, 16(4), 1-9. https://doi.org/10.11144/Javeriana.upsy16-4.vqsc

\begin{abstract}
To validate the questionnaire "Stage of Change in Behavior of Scholars in Eating Habits and Physical Activity" (CEHAF). It is based on the Transtheoretical Model, and it intends to be a useful tool for developing strategies against childhood obesity. It measures knowledge, attitudes, and habits towards nutrition and physical activity. Observational, crosssectional, randomized, and multi-center study in a sample of 1671 Mexican school-age children, from 8 to 12 years old, both genders. The CEHAF questionnaire is self-administered and consists of 35 questions, including 18 multiple choices, on habits and attitudes towards alimentation and physical activity. Reliability analysis through Cronbach's alpha resulted in an alpha coefficient of 0.845. The exploratory factor analysis revealed three theoretically-congruent factors. The final version of the CEHAF questionnaire was conformed of 14 items. The psychometric characteristics of the CEHAF questionnaire indicate that it is a valid and reliable tool for assessing the stage of change in schoolage population.

Keywords

Childhood obesity; Scale validation; Transtheoretical model.
\end{abstract}

\section{RESUMEN}

Validar el cuestionario "Etapa de cambio del comportamiento de escolares en hábitos alimentarios y actividad física" (CEHAF), el cual está basado en el modelo transteórico, y pretende ser una herramienta útil para desarrollar estrategias para combatir la obesidad infantil. Dicha herramienta mide conocimientos, actitudes y hábitos sobre nutrición y actividad física. Estudio observacional, transversal y aleatorizado en una muestra de 1671 estudiantes mexicanos, de 8 a 12 años de 
edad, ambos sexos. El cuestionario CEHAF es autoadministrado y se conforma por 35 preguntas, incluyendo 18 de opción multiple, sobre hábitos de alimentación y actividad física. Resultados: El análisis de confiabilidad mediante alfa de Cronbach resultó en un coeficiente alfa de 0.845. El análisis factorial exploratorio reveló tres factores teóricamente congruentes. La versión final del cuestionario CEHAF estuvo compuesta de 14 items. Las características psicométricas del cuestionario CEHAF lo vuelven una herramienta válida y confiable para evaluar la etapa de cambio en estudiantes de escuela primaria.

Palabras clave

Obesidad infantil; Validación de escalas; Modelo Transteórico.

Obesity is a chronic disease characterized by an abnormal and excessive accumulation of body fat (Norma Oficial Mexicana, 2010), to such degree that it becomes a health risk (Koukourikos, Lavdaniti, \& Avramika, 2013). Its etiology is complex and multifactor (Santaliestra-Pasías, Rey-López, \& Moreno Aznar, 2013). The main causes of obesity include an imbalance between energy intake and expenditure, genetics, behavior, socioeconomic, and ecological factors (Dhir \& Ryan, 2010; Pérez-Morales, Bacardí-Gascón, Jiménez-Cruz, \& Armendáriz-Anguiano, 2009). It can start in childhood, and is considered a public health problem worldwide (Liria, 2012). Mexico occupies the first place in childhood obesity worldwide (Ortega-Cortés et al., 2014): The prevalence in 2012 of overweight and obesity was 34.4 percent combined (19.8 and 14.6 percent, respectively), which represents about $5,664,870$ children with overweight and obesity nationwide (Gutiérrez, Rivera, Shamah, Oropeza, \& Hernández Ávila, 2012).

About $70-80 \%$ of children and adolescents diagnosed with obesity will become obese adults (Binkiewicz-Glińska et al., 2012; Cowie, 2014; Wong \& Leatherdale, 2009). They have an increased risk of presenting cardiovascular and endocrine disorders such as metabolic syndrome, fasting insulin resistance, myocardial infarction, and stroke. Other conditions may involve nephropathy, fatty liver, and postural deformities. Obese girls often present polycystic ovarian syndrome and precocious puberty (Binkiewicz-
Glińska et al., 2012). Consequences also imply psychological problems such as eating disorders, depression, stress, anxiety about self-appearance, and low self-esteem (Binkiewicz-Glińska et al., 2012; Wang et al., 2013). Obese children are at more risk of being isolated, intimidated, insulted, or aggressed by their classmates with normal physical complexion, which can lead to low academic performance, absentism, and a general poor adaptation capacity at school (García, 2010).

Nowadays, children have become more sedentary by spending more hours watching television, playing video games, or surfing on the internet, and less hours participating in physical activities such as walking or sports (Cowie, 2014; Meléndez, Cañez, \& Frías, 2010). Television remains as the main source of sedentary lifestyle, therefore, the American Academy of Pediatrics has recommended a maximum of 2 hours of television per day for children and adolescents (Pérez Rodríguez-Martín, Ruiz, Nieto, \& Campoy, 2010). Furthermore, the World Health Organization (OMS) and the National Commission of Physical Culture and Sport (CONADE) in Mexico, both recommend at least 60 minutes of moderate to vigorous physical activity (PA) for this specific population (World Health Organization, 2010; Comisión Nacional de Cultura Física y Deporte, 2010).

Schools are the key places for receiving education about healthy lifestyles, this due the presence of qualified personnel and because of the long time that children spend at school (Pérez-Morales et al., 2009). Interventions at school-age are crucial, since habits and attitudes acquired at this age can prevail throughout life (Escalante-Guerrero, de la Roca-Chiapas, \& Macías-Cervantes, 2012). In Mexico, the school interventions focus at increasing PA, water, fruit, vegetables, legumes, and whole grains intake, substituting whole milk for low fat milk, and decreasing the sugar and greasy foods intake (Villalobos, Campos Nonato, Camarillo, \& Enríquez Santamaría, 2012). Nevertheless, school interventions have not yielded the expected results. A meta-analysis carried out by Pérez-Morales et al.., where 10 randomized 
controlled trials from 2006 to 2009 were analyzed, reflected a lack of effect of these interventions in the reduction of BMI (PérezMorales et al., 2009).

This could be translated as a poor adherence to nutrition and PA recommendations, which implies changing cognitive, emotional, and behavioral habits (Villalobos et al., 2012).

It is necessary to develop comprehensive strategies with measurable impact that address knowledge, attitudes, and habits towards nutrition and PA (Escalante-Guerrero et al., 2012). For these purposes, the trans-theoretical model of health behavior change (TTM) can result helpful, since it evaluates the readiness to change a behavior (Greene et al., 1999). The TTM involves a progression process through a series of five temporal stages that compose the behavior change (Di Noia \& Prochaska, 2010): precontemplation (no intention of changing in the next 6 months), contemplation (intention to change within the next 6 months), preparation (intending to change in the next month), action (recent change in the past 6 months), and maintenance (maintaining change from 6 months to about 5 years) (Greene et al., 1999; Prochaska \& Velicer, 1997).

Questionnaires and scales about the stage of change of an individual can be useful to assess the attitudinal factors and the willingness to change the lifestyle (Escalante-Guerrero et al., 2012). Several instruments for health-related issues have been developed worldwide based on the TTM, showing adequate psychometric properties (Andrés, Saldaña, \& Gómez-Benito, 2011; Blaney et al., 2012; Henry, Smith, \& Ahmad, 2013; Kushida \& Murayama, 2012; Sarbandi, Niknami, Hidarnia, Hajizadeh, \& Montazeri, 2013; Vereecken et al., 2009). In Mexico, literature suggests that just a few surveys and questionnaires based on the TTM have been created or adapted, from which most involve just PA and are directed to an adult population (Esparza del Villara et al., 2013; Villalobos et al., 2012). Ochoa-Meza, Sierra, Pérez-Rodrigo and Aranceta-Bartrina (2014) validated the TTM-based questionnaire Pro Children Project for assessing psychosocial factors associated with fruit and vegetables consumption in a sample of Mexican school-age children. Content validity was good among experts (kappa $=0.69)$ and very good among school-age children $($ kappa $=0.93)$. Construct validity presented an internal structure of 7 factors with a reduced explained variance $37.87 \%$ in fruits and $48.18 \%$ in vegetables). Internal consistency values were from low to moderate (Cronbach's alpha $=$ 0.55-0.83).

Therefore, the aim of this study was to validate a TTM-based, culturally-relevant (García y Barragán, García Campos, \& Reyes Lagunes, en prensa) instrument for school-age children that included both alimentation and PA topics, and that could identify at which stage of change the child currently is, with the goal of improving strategies and interventions targeted towards childhood obesity.

\section{Method}

\section{Ethic clearance}

The study was approved by the University of Guanajuato Psychology Department ethics committee.

\section{Instrument}

The "Stage of Change in Behavior of Scholars in Eating habits and Physical Activity" (CEHAF) is a self-administered questionnaire. It consists of 35 questions, including 18 multiple choices, on habits and attitudes towards alimentation and PA. For the purposes of this project, breakfast contents and food eaten as snacks were considered the main habits to change, since breakfast is the meal skipped more often (Prochaska, 2008). PA was defined as any movement of the musculoskeletal system to increase energy expenditure by individual activities, recreational or sports, considering as an indicator the number of minutes per week allocated to any of these practices (Johnson et al., 2008). Individuals were classified as sedentary 
if they do not perform any type of recreational PA, exercise or sport, during their free time and/ or assign more than 2 hours a day for watching television, using the computer, or playing video games.

\section{Sample and procedure}

This was an observational, cross sectional study. The participants were 1671 school-age children from several primary schools across Mexico (49.2\% male, $50.8 \%$ female). They were studying from 4th through 6th grade. The ages of the participants were between 8 and 12 years old, since evidence shows that children at these ages have acquired greater autonomy to internalize knowledge and change attitudes towards food and PA (Daniels \& Greer, 2008). The CEHAF questionnaire was applied collectively during school hours in the presence of the class teacher and the researchers, who clarified emerging doubts during the process.

\section{Analyses}

For the scale validation, the Reyes Lagunes and García y Barragán methodological and statistical proposal (Reyes Lagunes \& García y Barragán, 2008) was implemented, which involves frequency analyses, item discrimination analyses through t-tests, reliability analyses through Cronbach's alpha, and an exploratory factor analysis to obtain evidence of construct validity. SPSS v.21 statistical software was used to perform these analyses.

\section{Results}

For the items associated with eating habits, a frequency analysis was implemented with the purpose of verifying the correct data collection and also to corroborate that all response options resulted appealing for the participants. A new variable was created with the sums of the scores of every item, and the values for percentiles 25 and 75 were obtained. With these values, a new dichotomous variable was created and utilized as grouping variable for executing $t$-tests for independent samples in order to verify that the items discriminated between high and low scores. An internal consistency analysis using Cronbach's alpha was implemented to determine the scale's reliability. Three items were deleted for showing low item-total correlations. This changed the alpha coefficient from 0.671 to 0.845, with 15 items remaining (table 1 ).

\section{TABLE 1}

Items remaining after Cronbach's alpha analysis

\begin{tabular}{llll}
\hline & CTIC & SMC & CAID \\
\hline $\begin{array}{l}\text { Physical Activity } \\
\text { 1. Do you usually go play outdoors? (sport units, parks) }\end{array}$ & 0.599 & 0.471 & 0.835 \\
2. Do you practice any sport? & 0.545 & 0.410 & 0.837 \\
4. Would you decrease that amount of time? [Hours / day watching & 0.542 & 0.333 & 0.837 \\
TV] & & & \\
6. Would you decrease that amount of time? [Hours / day using & 0.317 & 0.154 & 0.851 \\
computer] & & & \\
8. Would you decrease that amount of time? [Hours / day playing & 0.325 & 0.157 & 0.848 \\
videogames] & & & \\
Alimentation & & & \\
9. Do you choose the food you eat in the day? & 0.525 & 0.314 & 0.838 \\
10. Do you participate in the preparation of the food you eat? & 0.564 & 0.351 & 0.836 \\
11. Do you avoid high-fat food? & 0.635 & 0.506 & 0.833 \\
12. Do you avoid foods with high content of sugar? & 0.592 & 0.479 & 0.835 \\
13. Do you avoid drinking beverages with high content of sugar? & 0.620 & 0.486 & 0.834 \\
14. Do you change the way you eat your meals to reduce their content & & & \\
of fat? (Like taking off the skin of the chicken) & 0.616 & 0.482 & 0.833 \\
15. Do you prefer lower-fat food preparations? (Like roasted or boiled & & & \\
rather than fried or breaded meals) & 0.587 & 0.462 & 0.835 \\
16. Do you have breakfast every day? & & & \\
17. How many times a week do you eat fruit? & 0.477 & 0.276 & 0.84 \\
18. How many times a week do you eat vegetables? & 0.49 & 0.265 & 0.841 \\
& 0.333 & 0.137 & 0.865 \\
\hline
\end{tabular}

$$
\begin{gathered}
\text { Note:CTIC = Corrected Total-Item Correlation. } \\
\text { SMC = Squared multiple correlation. } \\
\text { CAID = Cronbach's Alpha if Item Deleted. } \\
\text { Source: own source. }
\end{gathered}
$$

Following this, an exploratory factor analysis with oblique rotation was executed to test construct validity. Three factors were obtained, which together explained $52.498 \%$ of the variance. Since items 9 and 10 had very low factor loadings, these were omitted from the final structure (table 2). 
TABLE 2

\section{Resulting factor structure}

\begin{tabular}{|c|c|c|c|}
\hline & F1 & $\mathrm{F} 2$ & F3 \\
\hline 12. Do you avoid foods with high sugar content? & 0.815 & & \\
\hline $\begin{array}{l}\text { 15. Do you prefer lower-fat food preparations? (Like roasted or boiled } \\
\text { rather than fried or breaded meals) }\end{array}$ & 0.814 & & \\
\hline 11. Do you avoid greasy food? & 0.805 & & \\
\hline $\begin{array}{l}\text { 14. Do you change the way you eat your meals to reduce their content of } \\
\text { fat? (Like taking off the skin of the chicken) }\end{array}$ & 0.777 & & \\
\hline 13. Do you avoid drinking beverages with high content of sugar? & 0.757 & & \\
\hline $\begin{array}{l}\text { 8. Would you reduce that amount of time? [Hours per day playing } \\
\text { videogames] }\end{array}$ & & 0.770 & \\
\hline $\begin{array}{l}\text { 6. Would you reduce that amount of time? [Hours per day using the } \\
\text { computer] }\end{array}$ & & 0.753 & \\
\hline 4. Would you reduce that amount of time? [Hours per day watching TV] & & 0.499 & \\
\hline 18. How many times a week do you eat vegetables? & & & 0.734 \\
\hline 17. How many times a week do you eat fruit? & & & 0.659 \\
\hline 1. Do you usually go play outdoors? (sport units, parks) & & & 0.627 \\
\hline 16. Do you have breakfast every day? & & & 0.534 \\
\hline 2. Do you practice any sport? & & & 0.498 \\
\hline
\end{tabular}

Note: $\mathrm{F}=$ Factor. Extraction Method:

Principal Component Analysis. Rotation Method: Oblimin with Kaiser Normalization.

The rotation converged in 6 iterations.

Source: own source.

A bivariate Pearson's correlation analysis was implemented between the three factors. A moderate association was found, highlighting, with a correlation value of 0.549 , the relation between the factors 1 and 3 (table 3 ).

TABLE 3

Correlations between factors

\begin{tabular}{cccc}
\hline Factor & F1 & F2 & F3 \\
\hline 1 & 1 & $0.403^{* *}$ & $0.549^{* *}$ \\
2 & $0.403^{* *}$ & 1 & $0.389^{* *}$ \\
3 & $0.549^{* *}$ & $0.389^{* *}$ & 1 \\
\hline
\end{tabular}

Note:Pearson's correlation analysis.

** Correlation is significant

at a significance level of 0.01 .

Source: own source.

Table 4 shows that means for factors 1 and 2 were below the theoretical mean (which corresponds to the value 3 ). In contrast, factor 3 had a mean higher than the theoretical mean. Cronbach's alpha analyses indicated that only factors one and two presented an adequate reliability.
TABLE 4

Psychometric characteristics of the factors

\begin{tabular}{|c|c|c|c|c|}
\hline Factor & Name & Mean & SD & $\alpha$ \\
\hline 1 & Avoidance of non-healthy foods & 2.9579 & 1.282 & 0.847 \\
\hline 2 & Physical activation & 2.3269 & 1.409 & 0.544 \\
\hline 3 & Healthy habits & 3.8222 & 1.476 & 0.635 \\
\hline
\end{tabular}

\section{Discussion}

In the present study, the psychometric properties of questionnaire "Stage of Change in Behavior of Scholars in Eating Habits and Physical Activity" were investigated and validated. An alpha coefficient of 0.845 was obtained for the whole scale, which indicates a high internal consistency. Concerning the analysis of the resulting factor structure, theoretical congruence was found between the factors and the items that conformed them. The first factor relates to the attempts at eliminating or reducing fat and sugars in the daily diet. The second factor consisted of three items associated to physical activity, opposed to the sedentary lifestyle caused by spending time in front of electronic media. Finally, the third factor gathers items which relate to healthy habits (both physical activation and alimentation).

Since the mean scores of factors 1 and 2 were below the theoretical mean, this could indicate that there is only an intention to improve on these health habits, but no actual actions to change them yet. Factor 3 had a mean higher than the theoretical, which could mean that the participants have less than six months performing these behaviors associated with healthy habits. The alpha coefficient of factor two points out that it does not have a sufficient reliability to use it as an individual scale, however, it can still be used as part of the whole scale.

In conclusion, the psychometric properties of the CEHAF questionnaire indicate that it is a valid and reliable instrument for assessing the stage of change in school-age children. It can be utilized in school interventions to dissuade sedentary lifestyle and inadequate nutrition habits, or maintaining the current 
conditions if these are found appropriate. This instrument proved to comprehensively cover the fundamental aspects that involve the issue of childhood obesity: Diet, PA, and habits regarding the willingness to change (see the full questionnaire in Appendix).

\section{Acknowledgements}

The authors would like to thank the study participants, their parents who gave their informed consent, as well as the Secretaries of Health who provide facilities for the development of the research.

\section{References}

Andrés, A., Saldaña, C., \& Gómez-Benito, J. (2011). The transtheoretical model in weight management: Validation of the processes of change questionnaire. Obesity Facts, 4, 433-442. https:// doi.org/10.1159/000335135

Binkiewicz-Glińska, A., Bakuła, S., KusiakKaczmarek, M., Kowalski, I. M., Zaborowska-Sapeta, K., ProtasiewiczFałdowska, H., \& Białkowska, M. (2012). Obesity prevention in children and adolescents. Current recommendations. Polish Annals of Medicine, 19, 158-162. https:// doi.org/10.1016/j.poamed.2012.07.003

Blaney, C. R. M., Paiva, A., Redding, C., Rossi, J., Blissmer, B., \& Oatley, K. (2012). Validation of the measures of the transtheoretical model for exercise in an adult African-American sample. American Journal of Health Promotion, 26, 317-326. https://doi.org/10.4278/ ajhp.091214-QUAN-393

Cowie, J. (2014). Measurement of obesity in children. Primary Health Care, 24, 18-23. https://doi.org/10.7748/phc.24.7.18.s28

Daniels, S. R., \& Greer, F. R. (2008). Lipid Screening and cardiovascular health in childhood. Pediatrics, 122, 198-208. https:// doi.org/10.1542/peds.2008-1349
Dhir, S., \& Ryan, F. (2010). Measurement, causes and management of overweight and obesity in children. Community Practitioner, 83(1), 32-34.

Di Noia, J., \& Prochaska, J. O. (2010). Dietary stages of change and decisional balance: $\mathrm{A}$ meta-analytic review. American Journal of Health Behavior, 34(5), 618-632.

Escalante-Guerrero, C. S., de la Roca-Chiapas, J. M., \& Macías-Cervantes, M. H. (2012). Knowledge, attitudes, and behavior concerning nutrition and physical activity in Mexican children. American Journal of Health Behavior, 36, 424-431. https:// doi.org/10.5993/AJHB.36.3.12

Esparza del Villara, O., Carrillo Saucedo, I., Quiñones Soto, J., del Castillo Arreola, A., Guzmán Saldaña, R., Ochoa Alcaraz, S., \& Sánchez Sosa, J. (2013). Cuestionario de ejercicio basado en el modelo transteórico de la conducta en una muestra mexicana. Enseñanza e Investigación en Psicología, 18(1), 125-141.

García, N. D. (2010). Importancia del apoyo social en la problemática de la obesidad infantil. Calidad de Vida UFLO, 1, 125-138.

García y Barragán, L. F., García Campos, T., \& Reyes Lagunes, I. (en prensa). Propuesta de procedimiento para la adaptación de instrumentos psicológicos culturalmente relevantes.

Greene, G. W., Rossi, S. R., Rossi, J. S., Velicer, W. F., Fava, J. L., \& Prochaska, J. O. (1999). Dietary applications of the stages of change model. Journal of the American Dietetic Association, 99, 673-678. https:// doi.org/10.1016/S0002-8223(99)00164-9

Gutiérrez, J. P., Rivera, J., Shamah, T., Oropeza, C., \& Hernández Ávila, M. (2012). Encuesta Nacional de Salud y Nutrición. Cuernavaca, MX: Instituto Nacional de Salud Pública.

Henry, B. W., Smith, T. J., \& Ahmad, S. (2013). Psychometric assessment of the Behavior and Attitudes Questionnaire for healthy habits: Measuring parents' views on food and physical activity. Public 
Health Nutrition, 17, 1004-1012. https:// doi.org/10.1017/S136898001200554X

Johnson, S., Paiva, A., Cummins, C., Johnson, J., Dyment, S., Wright, J., \& Sherman, K. (2008). Transtheoretical modelbased multiple behavior intervention for weight management: Effectiveness on a population basis. Preventive Medicine, 46, 238-246. https://doi.org/10.1016/ j.ypmed.2007.09.010

Koukourikos, K., Lavdaniti, M., \& Avramika, M. (2013). An overview on childhood obesity. Progress in Health Sciences, 3(1), 128-133.

Kushida, O., \& Murayama, N. (2012). Assessment of the validity and reliability of the processes of change scale based on the transtheoretical model of vegetable consumption behavior in Japanese male workers. Nihon Koshu Eisei Zasshi, 59, 861-870.

Liria, R. (2012). Consecuencias de la obesidad en el niño y el adolescente: un problema que requiere atención. Revista Peruana de Medicina Experimental y Salud Pública, 29(3), 357-360.

Meléndez, J. M., Cañez, G. M., \& Frías, H. (2010). Comportamiento alimentario y obesidad infantil en Sonora, México. Revista Latinoamericana de Ciencias Sociales, Niñez y Juventud, 8, 1131-1147.

México, Comisión Nacional de Cultura Física y Deporte. (2010). Guía de Activación Física. Educación Primaria. México: Secretaría de Educación Pública. Recuperado de http://activate.gob.mx/Doc umentos/guiaActivacionPrimaria.pdf

México, Norma Oficial Mexicana. (2010). Para el tratamiento integral del sobrepeso y la obesidad. NOM-008-SSA3-2010. México, D. F., a 7 de julio de 2010. La Subsecretaría de Integración y Desarrollo del Sector Salud y Presidencia del Comité Consultivo Nacional de Normalización de Innovación, Desarrollo, Tecnologías e Información en Salud.

Ochoa-Meza, G., Sierra, J. C., Pérez-Rodrigo, C., \& Aranceta-Bartrina, J. (2014). Validación del cuestionario Pro Children Project para evaluar factores psicosociales del consumo de fruta y verdura en México. Salud Pública de México, 56(2), 165-179.

Ortega-Cortés, R., Hurtado-López, E. F., López-Beltrán, A. L., Trujillo-Trujillo, X. A., Tlacuilo-Parra, J. A., \& ColungaRodríguez, C. (2014). Caracterización de niños obesos con y sin diagnóstico de síndrome metabólico en un hospital pediátrico. Revista Médica del Instituto Mexicano del Seguro Social, 52(S1), 48-56.

Pérez-Morales, M., Bacardí-Gascón, M., Jiménez-Cruz, A., \& ArmendárizAnguiano, A. (2009). Intervenciones aleatorias controladas basadas en las escuelas para prevenir la obesidad infantil: revisión sistemática de 2006 a 2009. Archivos Latinoamericanos de Nutrición, 59(3), 253-259.

Pérez, S. V., Rodríguez-Martín, A., Ruiz, J. P., Nieto, J. M., \& Campoy, J. L. (2010). Hábitos y estilos de vida modificables en niños con sobrepeso y obesidad. Nutrición Hospitalaria, 25(5), 823-831. https://doi.org/10.3305/nh.2010.25.5.4683

Prochaska, J. O. (2008). Decision making in the transtheoretical model of behavior change. Medical Decision Making, 28, 845-849. https://https:// doi.org/10.1177/0272989X08327068

Prochaska, J. O., \& Velicer, W. F. (1997). The transtheoretical model of health behavior change. American Journal of Health Promotion, 12(1), 38-48.

Reyes Lagunes, I., \& García y Barragán, L. F. (2008). Procedimiento de validación psicométrica culturalmente relevante: un ejemplo. In R. Díaz Loving, R. Sánchez Aragón \& I. Reyes Lagunes (Eds.), La Psicología Social en México (Vol. 12, pp. 625-363). México: Asociación Mexicana de Psicología Social.

Santaliestra-Pasías, A., Rey-López, J., \& Moreno Aznar, L. (2013). Obesity and sedentarism in children and adolescents: What should be bone? Nutrición Hospitalaria, 28(Suppl. 5), 99-104. 
Sarbandi, F., Niknami, S., Hidarnia, A., Hajizadeh, E., \& Montazeri, A. (2013). The transtheoretical model (TTM) questionnaire for smoking cessation: Psychometric properties of the Iranian version. BMC Public Health, 13, 1186. https:// doi.org/10.1186/1471-2458-13-1186

Vereecken, C., De Henauw, S., Maes, L., Moreno, L., Manios, Y., Phillipp, K., \& De Bourdeaudhuij6, I. (2009). Reliability and validity of a healthy diet determinants questionnaire for adolescents. Public Health Nutrition, 12, 1830-1838. https:// doi.org/10.1017/S1368980008004655

Villalobos, V. E., Campos Nonato, I., Camarillo, G., \& Enríquez Santamaría, R. (2012). Instrumentos para evaluar el cambio de hábitos relacionados con el control de peso. Revista Salud Pública y Nutrición, 13(1). Recuperado de http://www.respyn.uanl.mx /xiii/1/comunicaciones/intrumento.htm

Wang, Y., Wu, Y., Wilson, R. F., Bleich, S., Cheskin, L., Weston, C., ... Segal, J. (2013). Childhood obesity prevention programs: Comparative effectiveness review and meta-analysis. Comparative Effectiveness Review, 115 (Report No. 13-EHC081-EF). Rockville, MD: Agency for Healthcare Research and Quality.

Wong, S. L., \& Leatherdale, S. T. (2009). Association between sedentary behavior, physical activity, and obesity: Inactivity among active kids. Preventing Chronic Disease, 6(1), A26.

World Health Organization. (2010). Recomendaciones mundiales sobre actividad física para la salud. Retrieved from http://www.who.int/dietphysicalactivi ty/publications/9789241599979/es/

\section{Appendix A}

\section{Questionnaire Stages of behavior change for food habits and physical activity}
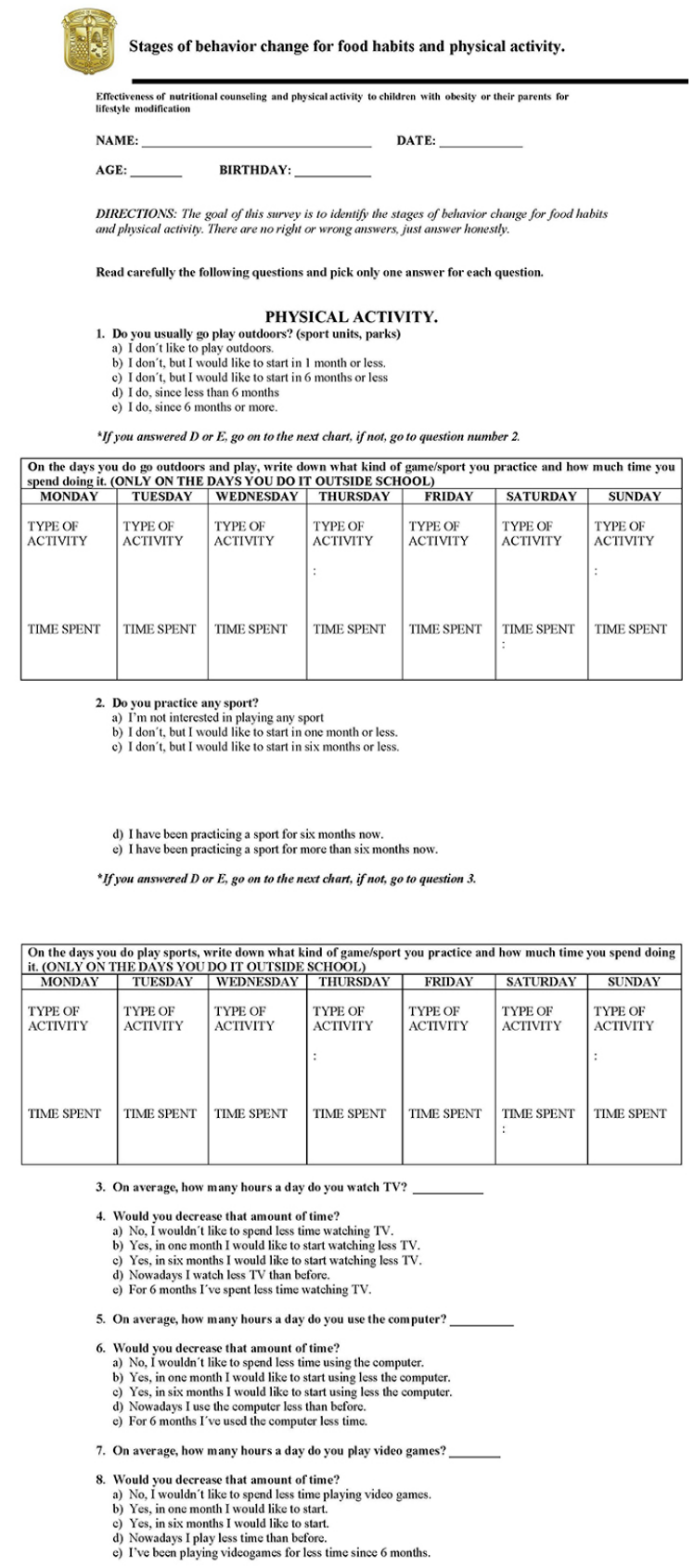


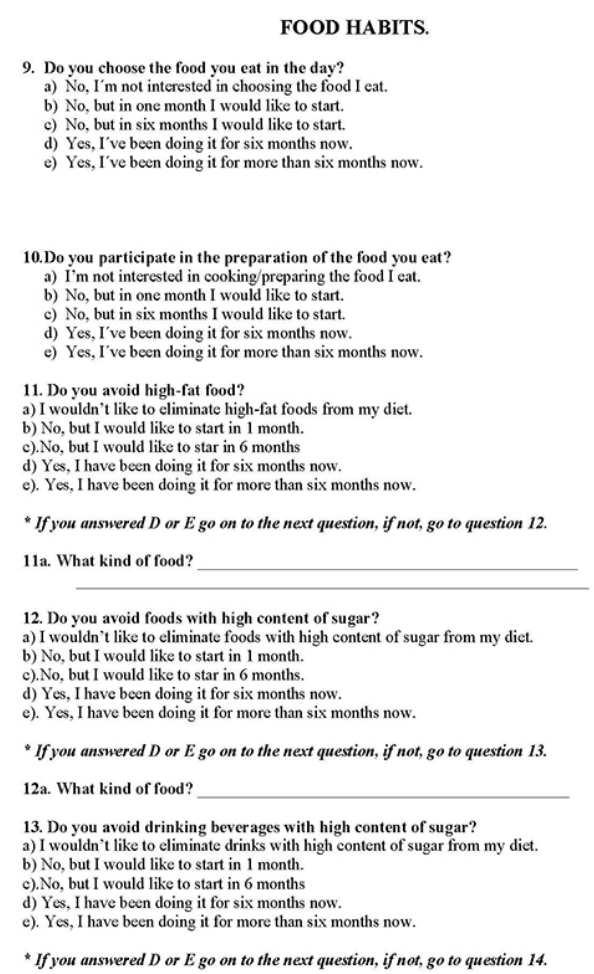

19. The number of meals you should have in one day is

$\begin{array}{lllll}\text { a) } 1 & \text { b) } 2 & \text { c) } 3 & \text { d) } 4 & \text { e) } 5\end{array}$

20. From the charts below, which one represents best all of the food groups?
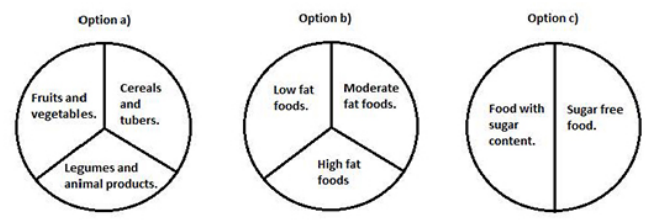

21. Which is the way of cooking using less fat?
a) Grill/roast, Boiled.

a) Grill/roast, Boiled.
b) Deep fried, Breaded

22. Which food contain more sugar?

a) Mayonnaise, Peanuts

23. Which beverages are more advisable to drink?

a) Soft drinks (such as coke)

b) Carton juice

d) Sports dinks (such as Gatorade or Powerade)

24. What kind of food do you usually buy with the Money you get every day?

25. From the things listed below, pick the ones that are physical activities. (You can pick more than one).

a) Walking

b) Biking.

c) Watching

e) Use the compu

f) Running/Jogging

g) Practice any sport

h) Sleeping

i) Swimming

j) Reading
k) Talking on the phone

1) Do your homework.
26. The maximum number of hours you spend watching television should be:

a) Less than one hour.

b) 1 hour.

d) 3 hours.

e) 4 hours.

f) 5 hours or more.

27. How many times a week should you do a physical activity?

b) 1

d) 4

e) 5

f) Every day.

28. The advisable amount of minutes you should do a physical activity is:

a) Less than 15 minutes

b) from 15 to 30 minutes

c) from 31 to 45 minutes

d) from 46 to 60 minutes

29. When you DON`T do any physical activity is because:

\section{Notes}

* Research article. 